\title{
LITERATUR REVIEW : PENERAPAN TEHNIK RELAKSASI GENGGAM JARI DALAM MENGURANGI INTENSITAS NYERI PADA KLIEN POST APPENDIKTOMY
}

Ahmad Muzaki ${ }^{1}$, Basuki Widiyanto², Wahyu Eko Yuliana ${ }^{3}$

\author{
Dosen Akademi Keperawatan Pemkab Purworejo ${ }^{1}$ \\ Perawat Puskemas Dadirejo ${ }^{2}$ \\ Mahasiswa Akademi Keperawatan Pemkab Purworejo ${ }^{3}$
}

Purworejo, (0275)3140576

Email: muzaki.ahmad1@gmail.com

\begin{abstract}
ABSTRAK
Latar belakang : Appendicitis merupakan peradangan apendik vermiformis. Dalam kasus ringan dapat sembuh tanpa perawatan, tetapi banyak kasus memerlukan laparotomy dengan menyingkirkan umbai cacing yang terinfeksi. Pasien post operasi appendicitis sering mengalami nyeri dikarenakan insisi pembedahan. Relaksasi genggam jari adalah tehnik non farmakologis untuk mengurangi nyeri. Tujuan : penelitian ini adalah untuk mengetahui pengaruh relaksasi genggam jari terhadap penurunan nyeri pada pasien post operasi appendicitis. Metode : penelitian yang digunakan pada penelitian ini adalah literature review mengenai tehnik relaksasi genggam jari. Penelusuran artikel dilakukan dengan google search dan proquest yang dipublikasikan sejak tahun 2015 sampai dengan 2020 yang diakses fulltext dalam format pdf. Hasil : ada pengaruh efek relaksasi genggam jari terhadap penurunan nyeri pada pasien post op appendiktomy. Kesimpulan : tingkat nyeri sebelum diberikan relaksasi genggam jari di dapatkan kategori nyeri sedang, dan sesudah diberikan kategori nyeri ringan. Secara signifikan ditunjukkan bahwa tehnik relaksasi genggam jari adalah tehnik yang efektif dalam mengurangi intensitas nyeri.
\end{abstract}

\section{Kata kunci : Relaksasi Genggam Jari, Nyeri, Appendicitis, Post Appendiktomy}

\section{ABSTRACT}

Background : Appendicitis is inflammation of vermiformis. In mild cases it can be cured without treatment, but many cases require a laparotomy by removing the tufts of infected worm tuft. Appendicitis post operative patien often experience pain due to a surgical incision. Finger-handed relaxtion is a non-pharmacological technique to reduce pain. Objective : this study was to determine the effect of hand-held relaxation on pain reduction in post operative appendicitis patients. Method : the research used in this study is a literature review on hand-held relaxation techniques. Searching for articles is carried out with Goggle Search and ProQuest from 2015 to 2020, accessed fulltext in pdf format. Result : there is an effect of the relaxation of the finger grip on pain reduction in post op appendectomy patients. Conclusion : the level of pain before being given a hand-held relaxation is in the category of moderate pain, and after being given a mild pain category. Significantly demonstrated that the hand-held relaxation techniques is an effective techniques in reducing pain intensity.

Keyword : Handheld Relaxation, Pain, Appendicitis, Post Appendiktomy 


\section{Pendahuluan}

Appendicitis merupakan peradangan apendik vermivormis dan merupakan penyebab masalah abdomen yang paling sering (Dermawan \& Rahayuningsih, 2010; dikutip dari jurnal Elma 2018). Kejadian apendicitis di dunia mencapai 321 juta kasus tiap tahun dan statistik di Amerika mencatat setiap tahun terdapat 20-35 juta kasus apendicitis (Rabie, 2006; dikutip dari jurnal Aan, 2017). Di Indonesia, jumlah pasien yang menderita penyakit apendicitis berjumlah sekitar $7 \%$ dari jumlah penduduk di Indonesia atau sekitar 179.000 orang.

Berdasarkan data dari Dinas Kesehatan Jawa Tengah (2009), jumlah kasus kesehatan appendicitis dilaporkan sebanyak 5.980 dan 177 diantaranya menyebabkan kematian. Jumlah penderita appendicitis tertinggi ada di Kota Semarang, yakni 970 orang. (Moch Fatkan, 2018). Appendiktomy merupakan tindakan pembedahan untuk mengangkat appendiks yang dilakukan untuk menurunkan resiko perforasi. Tindakan appendiktomy ini dapat menyebabkan terjadinya perubahan kontinuitas jaringan tubuh. (Jamaludin, 2017).

Dalam jurnal Moch Fatkan dkk (2018) appendiktomy adalah prosedur pembedahan yang dapat menyebabkan nyeri. Klien post appendiktomy membutuhkan perawatan yang maksimal yang dapat membantu pemulihan fungsi tubuh. Salah satu terapi nonfarmakologis yang dapat mengurangi nyeri adalah kompres hangat, nafas dalam, relaksasi spiritual, dan pemberian analgesik. Namun dalam penelitian ini peneliti akan mencoba dengan tehnik nonfarmakologis relaksasi genggam jari. Tehnik relaksasi genggam jari dengan tindakan untuk penanganan nyeri yang mempunyai beberapa tindakan. Dalam keadaan relaksasi secara alamiah akan memicu pengeluaran hormon endorphin, hormon ini ialah analgesik alami tubuh sehingga nyeri akan berkurang (Sulung N, Dian Rani S, 2007; dikutip dalam Asni Hasaini, 2019).

\section{Metode Penelitian}

Metode penelitian yang digunakan pada penelitian ini adalah literature review, yaitu mengumpulkan dan menganalisis artikel-artikel penelitian mengenai penerapan relaksasi genggam jari. Penelusuran artikel dilakukan dengan pendekatan data (database) seperti Google Scholar atau Google Cendekia dengan menggunakan kata kunci seperti "genggam jari + post appendiktomy", "efektifitas genggam jari + nyeri + post appediktomy", genggam jari post appendiktomy + nyeri", "penurunan nyeri post appendiktomy", "tehnik relaksasi genggam jari post appendiktomy". Artikel yang dipilih adalah artikel yang dipublikasikan sejak tahun 2015 sampai dengan 2020 yang dapat diakses fulltext dalam format pdf berbahasa Indonesia. Analisa data dilakukan dengan cara mendiskusikan dan meringkas literatur kemudian membandingkan beberapa literatur dan selanjutnya dituangkan dalam pembahasan. Dalam mereview sebuah 
literatur bisa melakukannya dengan beberapa

cara, diantaranya: Mencari kesamaan

(Simmiliarity), mencari ketidaksamaan

(Contrast), memberikan pandangan (Criticze), membandingkan (Compare) dan meringkas (Summarize).

\section{Hasil}

Hasil analisis literatur review ini disajikan dalam Tabel 1.

Tabel 1. Hasil Rekapitulasi Artikel Literatur Review

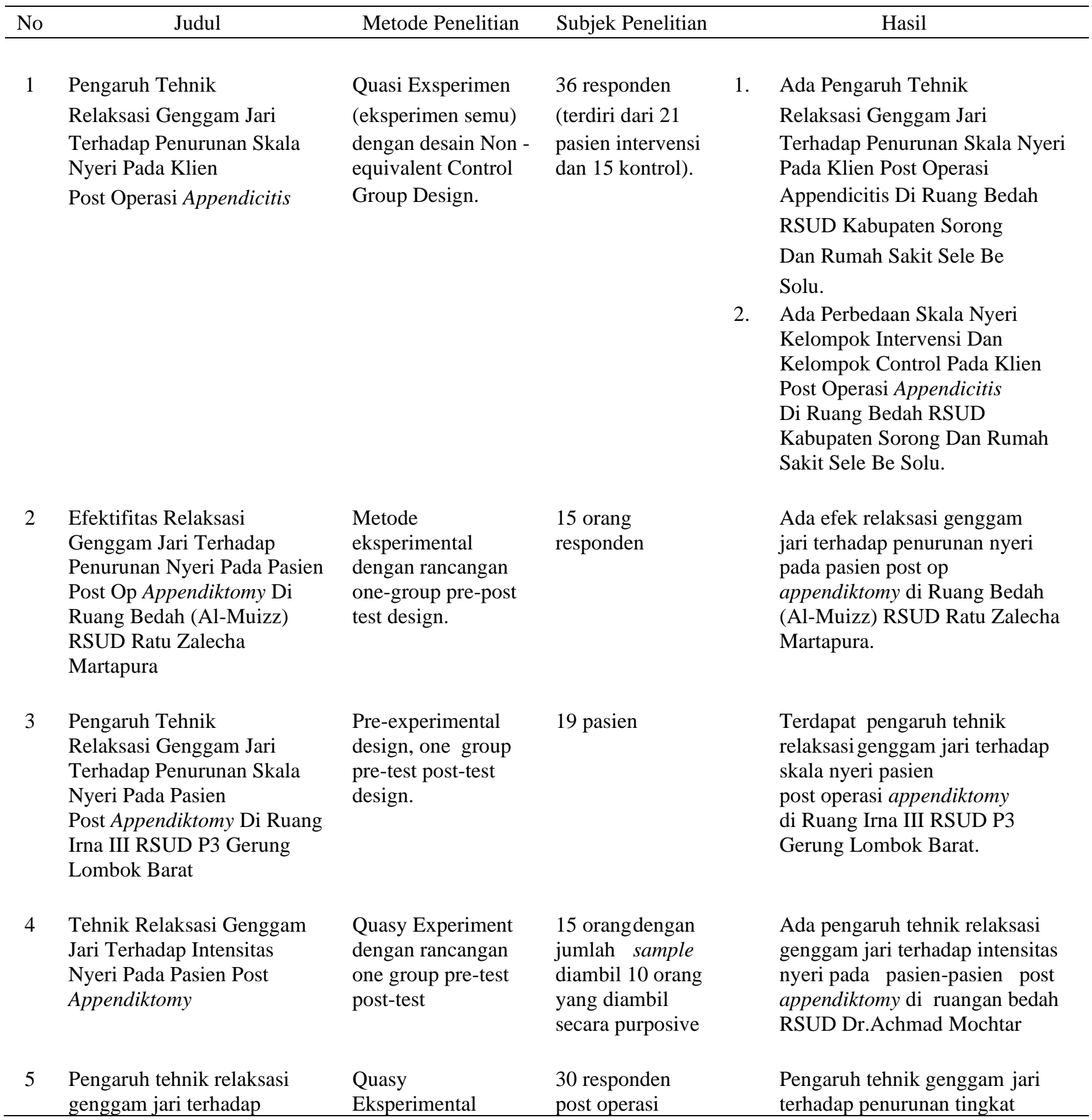


penurunan tingkat nyeri pasien post operasi appendiktomy di RSUD Dr. H. Soewondo Kendal pre and post without control
Test

appendiktomy nyeri pada pasien post operasi appendiktomy di RSUD Dr.H. Soewondo Kendal

\section{Pembahasan}

Relaksasi merupakan kebebasan mental dan fisik dari ketegangan dan stress, karena dapat mengubah persepsi kognitif dan motivasi efektif pasien. Tehnik relaksasi membuat pasien dapat mengontrol diri ketika terjadi rasa tidak nyaman atau nyeri, stress fisik dan emosi pada nyeri. Relaksasi genggam jari adalah sebuah tehnik relaksasi yang sangat sederhana dan mudah dilakukan oleh siapapun yang berhubungan dengan jari tangan serta aliran energy didalam tubuh kita (Moch Fatkan, 2018).

Tehnik genggam jari tersebut disebut juga finger hold. Tehnik relaksasi genggam jari, yang dimana tehnik ini mudah digunakan oleh siapapun yang berhubungan dengan jari tangan dan aliran energy didalam tubuh, terdapat kombinasi yaitu relaksasi nafas dalam, meggunakan waktu yang relatif singkat.

Menggenggam jari sambil mengatur nafas (relaksasi) dapat mengurangi ketegangan fisik dan emosi, karena genggaman jari akan menghangatkan titik-titik keluar dan masuknya energy meridian (energy channel) yang terletak pada jari tangan kita. Titik-titik refleksi pada tangan akan memberikan rangsangan secara reflex (spontan) pada saat genggaman. (Sulung N, Dian Rani S, 2007; dikutip dalam Asni Hasaini, 2019).
Menggenggam jari sambil mengatur nafas (relaksasi) dilakukan selama kurang lebih 3-5 menit dapat mengurangi ketegangan fisik dan emosi, karena genggaman jari akan menghangatkan titik-titik keluar dan masuknya energy meridian (emergency channel) yang terletak pada jari tangan kita. Titik-titik refleksi pada tangan akan memberikan rangsangan secara refleks (spontan) pada saat genggaman. Rangsangan tersebut akan mengalirkan gelombang listrik menuju otak yang akan diterima dan diproses dengan cepat, lalu diteruskan menuju saraf pada organ tubuh yang mengalami gangguan, sehingga penyumbatan di jalur energi menjadi lancar.

Mekanisme relaksasi genggam jari ini dijelaskan melalui teori gatecontrol yang menyatakan bahwa stimulasi kutaneous mengaktifkan transmisi serabut saraf sensori Abeta yang lebih besar dan lebih cepat.

Penelitian yang dilakukan oleh Neila Sulung dkk, (2017) pada pasien post appendiktomy di RSUD Dr. Achmad Mochtar Bukittinggi menunjukkan hasil bahwa pelaksanaan tehnik relaksasi genggam jari berpengaruh terhadap pengurangan rasa nyeri insisi post appendiktomy.

Hasil yang sama juga diperoleh dalam penelitian yang dilakukan oleh Asni Hasaini (2019) yang melakukan relaksasi genggam jari di ruang Bedah Al-Muizz RSUD Ratu Zalecha 
Martapura dengan hasil ada penurunan nyeri pasien post op appendicitis. Pada tahun yang sama juga dilakukan penelitian oleh Ria Ariani dkk, (2019) bahwa tehnik relaksasi genggam jari juga mampu menurunkan nyeri pada pasien post operasi appendicitis yang dilakukan di Rumah Sakit Sele Be Solu Kota Sorong.

Penelitian terhadap pengaruh penurunan nyeri dengan tehnik relaksasi genggam jari juga didukung oleh penelitian terbaru yang dilakukan oleh Abdul Hayat dkk, (2020) dan Dwi Nur (2017) yang juga menunjukkan hasil yang sama yaitu ada pengaruh penurunan nyeri pasien post operasi appendicitis dengan tehnik relaksasi genggam jari.

Dari kelima jurnal yang di gunakan ada 3 jurnal yang terdapat kesamaan penggunaan metode penelitian yaitu Quasi Eksperimental. Ria Ariani (2019), Neila Sulung (2017), dan Dwi Nur (2017) menggunakan metode penelitian yang sama, namun dengan responden yang berbedabeda. Ria Ariani (2019) menggunakan 36 responden yang terbagi dalam 21 pasien intervensi dan 15 pasien control. Neila Sulung (2017) menggunakan responden sebanyak 15 yang terbagi dalam 10 orsng yang diambil secara purposive sampling dengan memperhatikan kriteria inklusi dan eksklusi sampel. Kriteria inklusi pada penelitiannya adalah pasien 15 tahun sampai 50 tahun. Yang terakhir dari Dwi Nur (2017) menggunakan 30 responden dengan data yang didapatkan sebanyak 83 orang yang menderita apendiksitis.
Asni Hasaini (2019) dan Abdul Hayat (2020) menggunakan metode penelitian yang sama yaitu eksperimental one group pre-post test design. Dengan responden yang berbeda yaitu 15 orang dan 19 orang yang mengalami post op appendiktomy. Quasi eksperimental merupakan penelitian yang memberikan perlakuan dan mengukur akibat perlakuan namun tidak menggunakan sampel acak untuk menyimpulkan perubahan yang disebabkan perlakuan tersebut. Metode penelitian quasi eksperimen bertujuan untuk menunjukkan hubungan sebab dan akibat dengan melibatkan kelompok control dan kelompok eksperimen. Sedangkan yang dilakukan dengan one group pre test - post test design yaitu penelitian eksperimen yang dilaksanakan pada satu kelompok saja yang dipilih secara random dan tidak dilakukan test kestabilan dan kejelasan keadaan kelompok sebelum diberikan perlakuan.

Pandangan penulis berdasarkan penelitian dari 5 jurnal diatas sependapat bahwa tehnik relaksasi genggam jari dapat menurunkan intensitas nyeri. Tehnik relaksasi genggam jari, yang dimana tehnik ini mudah digunakan oleh siapapun yang berhubungan dengan jari tangan dan aliran energy didalam tubuh. Relaksasi genggam jari dapat mengendalikan dan mengembalikan emosi yang akan membuat tubuh menjadi rileks. Kelemahan dari tehnik relaksasi genggam jari yaitu dilakukan dengan cara bertahap tidak seperti tindakan kolaborasi yang langsung bereaksi. Tehnik relaksasi genggam jari di lakukan 
secara berulang-ulang ketika pasien merasakan nyeri.

Dari beberapa literature di atas menunjukkan ada pengaruh tehnik relaksasi genggam jari terhadap penurunan intensitas nyeri pada pasien post appendiktomy. Tehnik relaksasi genggam jari dapat digunakan sebagai terapi nonfarmakologis untuk mengurangi nyeri yang dirasakan pasien post appendiktomy.

\section{Kesimpulan}

Berdasarkan uraian diatas dari 5 jurnal yang telah dilakukan review maka menunjukkan bahwa tehnik relaksasi genggam jari dapat digunakan sebagai terapi nonfarmakologis untuk mengurangi nyeri yang dirasakan pasien post appendiktomy. Hasil dari 5 jurnal diatas juga menunjukkan bahwa ada pengaruh tehnik relaksasi genggam jari terhadap penurunan nyeri pasien post appendiktomy. Tehnik relaksasi genggam jari yang dilakukan dengan cara genggam ibu jari selama kurang lebih 3-5 menit dengan nafas secara teratur dan kemudian seterusnya satu persatu beralih kejari selanjutnya dengan rentan waktu yang sama. Dapat menurunkan intensitas nyeri pada pasien post appendiktomy. Nyeri adalah pengalaman yang diekspresikan berbeda oleh setiap orang.

Nyeri pada pasien post appendiktomy merupakan nyeri yang timbul akibat luka sayatan pada daerah insisi setelah menjalani proses pembedahan untuk mengangkat umbai cacing yang terinfeksi.

\section{Ucapan Terimakasih}

Penulis mengucapkan terima kasih kepada Direktur Akper Pemkab Purworejo dan Ketua Lembaga Penelitian dan Pengabdian Masyarakat yang telah memberikan dukungan dalam penyelesaian publikasi ini.

\section{Daftar Pustaka}

Aini, Dwi Nur, Tamrin., \& Rilasadi. (2017). Pengaruh Tehnik Relaksasi Genggam Jari Terhadap Penurunan Tingkat Nyeri Pasien Post Operasi Appendiktomy Di RSUD Dr. H. Soewondo Kendal. Diakses pada tanggal 04 Juni 2020, pukul 22.00 WIB.

Andriyani, Elma R. (2018). Penerapan Mobilisasi Dini Pada Pasien Gangguan Pemenuhan Activities Daily Living Post Appendiktomy Di RSUD Sleman, Yogyakarta. Diakses pada 7 Oktober 2019, pukul 21.48 WIB.

Fatkan, Moch, Yusuf, Ah., \& Herisanti, Wesiana. (2018). Pengaruh Kombinasi Mobilisasi Dini Dan Relaksasi Spiritual Terhadap Tingkat Nyeri Klien Post Operasi Apendektomi, Surabaya. Vol 5. Diakses pada 7 Oktober 2019, pukul 22.20 WIB.

Hayat, Abdul, Ernawati \& Aryanti, (2020). Pengaruh Tehnik relaksasi genggam jari terhadap penurunan nyeri di RSUD P3 Gerung Lombok Barat. Vol 2 (1). Diakses pada tanggal 02 Mei 2020, pukul 21.00 WIB.

Hasaini, Asni. (2019). Efektifitas Relaksasi Genggam Jari Terhadap Penurunan Nyeri Pada Pasien Post Op Appendiktomi Di Ruang Bedah (Al-Muizz) RSUD Ratu Zalecha Martapura. Diakses pada tanggal 02 Mei 2020 pukul 20.00 WIB.

Jamaludin, Ulya, Nur.K. (2017). Pengaruh Terapi Guided Imagery Dan Iringan Musik Terhadap Penurunan Nyeri Pada 
Pasien Dengan Post Apendiktomi

Hari I di Ruang Cempaka RSUD

Sunan Kalijaga Demak. Vol 4 (2). Diakses pada 25 Februari 2020, pukul 21.00 WIB.

Rasyid, Ria Ariani, Norma., \& Samaran Elisabet. (2019). Pengaruh Tehnik

Relaksasi Genggam Jari Terhadap Penurunan Skala Nyeri Pada Klien Post Operasi Apendicitis. Vol XIII (02). Diakses pada tanggal 02 Mei 2020, pukul 21.00 WIB.Sulung, Neila., \& Rani, Sarah Dian. (2017).

TehnikRelaksasi Genggam Jari Terhadap Intensitas Nyeri Pada Pasien Post Appendiktomi. Diakes pada tanggal 02 Mei 2020, pukul 21.30 WIB.

Sutandi, Aan., \& Siamboton, Flora.R. (2017). Hubungan

Tingkat Pengetahuan Tentang Mobilisasi terhadap kemampuan mobilisasi pada pasien post operasi appendiktomi, vol 3. Diakses pada 20 Desember 2019, pukul 22.30 WIB. 